\title{
Genesis of some tertiary Indian coals from the chemical composition of ash - a statistical approach: Part 1
}

\author{
Arpita Sharma ${ }^{1}$, Ananya Saikia ${ }^{1}$, Puja Khare ${ }^{2}$ and B P Baruah ${ }^{1, *}$ \\ ${ }^{1}$ Coal Chemistry Division, CSIR-North East Institute of Science \& Technology, Jorhat 785 006, Assam, India. \\ ${ }^{2}$ Agronomy-Soil Division, CSIR-CIMAP, Lucknow 226 015, India. \\ *Corresponding author. e-mail: bpbaruah@yahoo.com
}

In the present investigation, 37 numbers of high sulphur tertiary coal samples from Meghalaya, India have been studied on the basis of proximate and ash analysis. Various statistical tools like Bivariant Analysis, Principal Component Analysis (PCA) and Hierarchical Clustering Analysis (HCA), and also the geochemical indicators were applied to determine the dominant detrital or authigenic affinity of the ash forming elements in these coals. The genetic interpretation of coal as well as the coal ash has been carried out based on chemical compositions of high temperature ash (HTA) by using Detrital/Authigenic Index. X-Ray Diffraction (XRD) analysis was also carried out to study the mineralogy of the studied coal ashes. Both statistical tools and geochemical indicators have confirmed the detrital nature of these coals as well as the ash forming elements.

\section{Introduction}

Coal, a highly heterogeneous material, formed by accumulation of various plant precursors has enrichment or depletion of different elements and mineral phases due to their diagenetic environment. The complex nature of coal is due to the presence of organic and inorganic constituents. The organic matter consists of different macerals with varying physical and chemical structures, while the inorganic matter is randomly dispersed in coal as mineral inclusions or dissolved salts mostly associated with the organic structure. Coal being a major source of energy, its fundamental properties is of paramount importance for the efficient use and development of clean coal technologies.

The ash yield of coal is considered to be one of the important characteristics to determine its quality. Vassilev et al. (1997) had provided the information about the genesis of coal formation through the interrelation study between the ash yield and their chemical compositions. The chemical composition of coal ash varies widely depending upon the inorganic and organic constituents of coal and their association with each other. Various authors (Thiessen 1945; Francis 1961; Dixon et al. 1964; Machowsky 1968; Shibaoka 1972; Stach et al. 1975; Jenkins and Walker 1978; Yudovich 1978; Berkowitz 1979; Adolphi and Storr 1985; Van der Flier-Keller and Fyfe 1988; Vassilev et al. 1997) have grouped the ash and inorganic constituents of coals into different classes as inherent adventitious (extraneous) and free dirt syngenetic and epigenetic primary, secondary, and tertiary, detrital and authigenic or biogenic (plant), sorption, concretion (diagenetic), chemigenetic, clastic (detrital) and infiltration (epigenetic). The source rock types, nature of the coal forming environment, conditions of burial and degree of coalification can be interpreted to infer the genesis of coal (Van der Flier-Keller and Fyfe 1988).

Keywords. Tertiary; Meghalaya; high sulphur coal; detrital/authigenic index; PCA; HCA; XRD. 
The statistical tools like Correlation Analysis, Principal Component Analysis (PCA) and Hierarchical Clustering Analysis (HCA) can also be applied to the dataset of ash and its chemical composition for understanding the origin of the coal formation. The literature on the statistical application for determining the origin of coals has been very scanty (Vassilev et al. 2010a). For the pyrolysis of tertiary Indian coals, Khare et al. (2011) have applied statistical parameters for the first time and established linkages between activation energies and properties of coals.

The geological studies of the coal deposits and sampling sites reveal that these tertiary coal deposits of Meghalaya, India were formed over the peripheral platform areas of Shillong plateau, which is an extension of the ancient Precambrian Indian Peninsular Shield. Occurrence of coals in Meghalaya, India are found in the areas of Garo $\left(25^{\circ} 16^{\prime} 30^{\prime \prime}-29^{\circ} 36^{\prime} \mathrm{N}, 89^{\circ} 40^{\prime}-\right.$ $\left.90^{\circ} 48^{\prime} \mathrm{E}\right)$, Khasi $\left(25^{\circ} 10^{\prime}-25^{\circ} 51^{\prime} \mathrm{N}, 90^{\circ} 44^{\prime}-91^{\circ} 49^{\prime} \mathrm{E}\right)$ and Jaintia Hills $\left(25^{\circ} 10^{\prime}-26^{\circ} 57^{\prime} \mathrm{N}, 90^{\circ} 34^{\prime}-95^{\circ} 04^{\prime} \mathrm{E}\right)$ (figure 1). In Garo Hills, out of the five coalfields, Siju, West Darrangiri are the most important and the coal seams occur in the Tura sandstone formation of the Jaintia Group. Thirteen coal fields occur in Khasi Hills out of which Langrin is the most important, occurring in the Lakadong sandstone formation. Among the 18 coalfields of Jaintia
Hills, Bapung coalfield is the most important coal bearing area and the coal seams occur in both the Lakadong and Therria Sandstone Formations (CMPDIL 1991; Misra 1992).

In the present investigation, an attempt has been made to establish the origin, geological formation and coal forming environment from ashforming elements of these coals by different geochemical and statistical parameters. So far, the correlation analysis for genesis of various types of coals from Australia, Bulgaria, USA, Japan, Canada, South Africa, China, Spain, and Ukraine had been reported (Vassilev et al. 2010a). But for tertiary Indian coals similar knowledge base is not available and hence an attempt has been made to establish the genesis of these coals by applying statistical tools in addition to the geochemical parameters. Therefore, this lack of information has motivated the addressing of this gap in the knowledge-base and to provide maximum relevant information about the genesis.

\section{Experimental}

Thirty seven freshly mined coal samples through grab sampling (sizes $0.5-3$ inches) from different coalfields belonging to Garo, Khasi, and Jaintia Hills of Meghalaya were used in this study. The

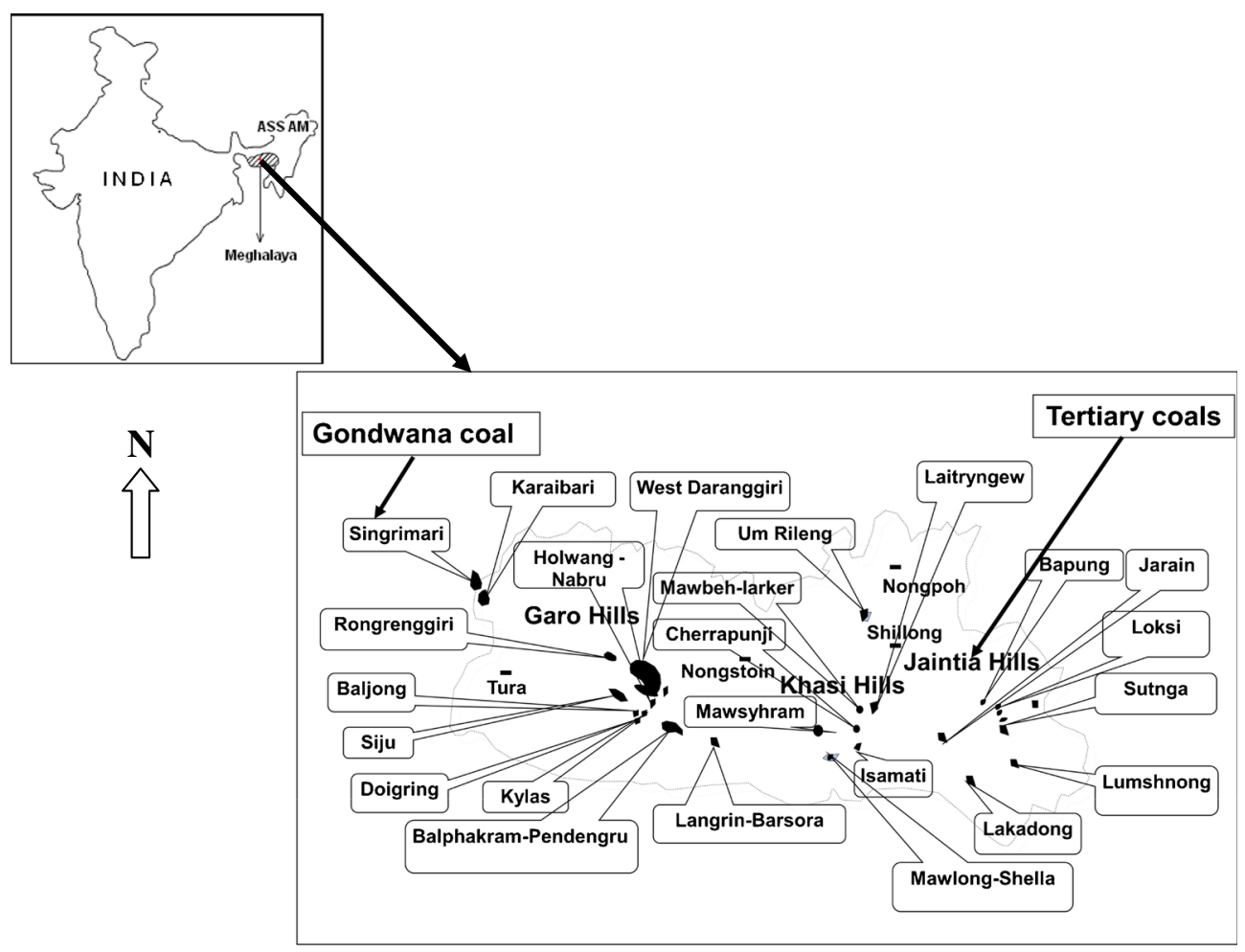

Figure 1. Meghalaya map showing coal-bearing areas (not in scale). 
air-dried samples were ground to $0.221 \mathrm{~mm}$ before use. The proximate and ultimate analyses were carried out by Proximate Analyzer (TGA 701, Leco, USA), CHN Analyzer (Truspec, Leco, USA), and Sulphur Determinator (S-144 DR, Leco, USA) respectively. The calorific values of coal samples have been determined by using Automatic Bomb Calorimeter (AC-350, Leco, USA). High Temperature Ash (HTA, $800^{\circ} \mathrm{C}$ ) analysis was carried out as per standard method (Himus 1954). Physicochemical characteristics of coals and chemical composition of ash are summarized in table 1.

X-ray diffraction analysis of some of the coal ash samples $(5$ nos.) were carried out in a computer controlled X-ray Diffractometer (Rigako, ULTIMA IV). These samples were selected to represent the group of samples in table 1.

\subsection{Statistical treatment of data}

The statistical tools such as Correlation Coefficient, Principal Component Analysis (PCA), and Hierarchical Cluster Analysis (HCA) have been applied to the datasets generated by using SPSS16 and XLSTATS software.

The correlation is one of the most common and useful statistical parameters that can show whether and how strongly different pairs of variables are related. Positive correlation between two elements is the simultaneous increase of the elements, whereas for the negative correlation, if one element increases the other decreases (Clark and Harper 2000).

The Principal Component Analysis (PCA) technique has been widely applied in the treatment of datasets of high complexity and allows finding out associations between variables thus reducing the dimensionality of the datasets. PCA provides a new set of orthogonal variables and establishes a linkage between the generated datasets. This technique extracts the eigen values and vectors from the covariance matrix from original variables. The eigen values of the principal components (PCs) are the measure of their associated variance, the participation of the original variables in the PCs given by the loading and individual transformed observations are called scores (Khare et al. 2011). Here, PCA was performed to study the origin of the coal samples under study.

Hierarchical clustering analysis is an exploratory multivariate method that describes the relationship among the variables. For HCA, the Ward's method was used to evaluate the distances between clusters. Hierarchical clustering joins the most similar observations, and successively connects the next most similar observations to these. The progression of levels of similarity at which observations merge is displayed as a dendrogram. Clustering is an efficient way of displaying complex relationships among many objects. However, the process of averaging together members of a cluster and treating them as a single new object introduces distortions into the dendrogram. This distortion becomes increasingly apparent as successive levels of clusters are averaged together. Cluster analysis has been applied to discriminate between ash and its chemical constituents.

\subsection{Calculation of detrital/authigenic index}

The detrital/authigenic index (DAI) based on chemical composition of high temperature coal ash (HTA) is used to assess the dominant detrital or authigenic affinity of the ash forming elements in coal. The DAI can be calculated by the following formula (Vassilev et al. 1997).

$$
\begin{aligned}
\mathrm{DAI}= & \left(\mathrm{SiO}_{2}+\mathrm{Al}_{2} \mathrm{O}_{3}+\mathrm{K}_{2} \mathrm{O}+\mathrm{TiO}_{2}+\mathrm{Na}_{2} \mathrm{O}\right) / \\
& \left(\mathrm{Fe}_{2} \mathrm{O}_{3}+\mathrm{CaO}+\mathrm{SO}_{3}+\mathrm{MgO}\right)
\end{aligned}
$$

\section{Results and discussions}

\subsection{Physico-chemical characterization of coal samples}

The studied coal samples are characterized by low to medium ash (4.1-26.9\%; values of sample nos. M2, M3 and M36 are not considered), high volatile matter $(22.8-38.89 \%)$, high sulphur $(2.87-6.96 \%)$ content, and high calorific values (4035-6990 kcal/kg; values of M3, M25, M36 are not considered) (table 1 ). The $\mathrm{H} / \mathrm{C}$ ratios $(0.79$ 1.26) of these coals are found to be higher than the other Indian coals. These coals have high hydrogen content and are suitable for combustion and conversion (i.e., liquefaction) processes. The characteristics of these coals are attributed to their formation over platform areas in estuarine and lagoonal environments, which are subjected to recurrent marine transgressions and regressions during tertiary period (Singh and Singh 2000; Baruah 2008).

From the physico-chemical characteristics of Meghalaya coals (table 1), these coals can be classified as sub-bituminous to high volatile bituminous in rank according to ASTM standards as it shows the characteristics of both lignite and bituminous, having carbon content (65.86-85.65\%), fixed carbon (52.13-63.84\%), and volatile matter $(36.15-48.90 \%)$ on pure coal basis. These tertiary Indian coals, on the basis of the moisture content and CV values (as received) could also be classified under the ligno-bituminous rank (Khare and Baruah 2010). 


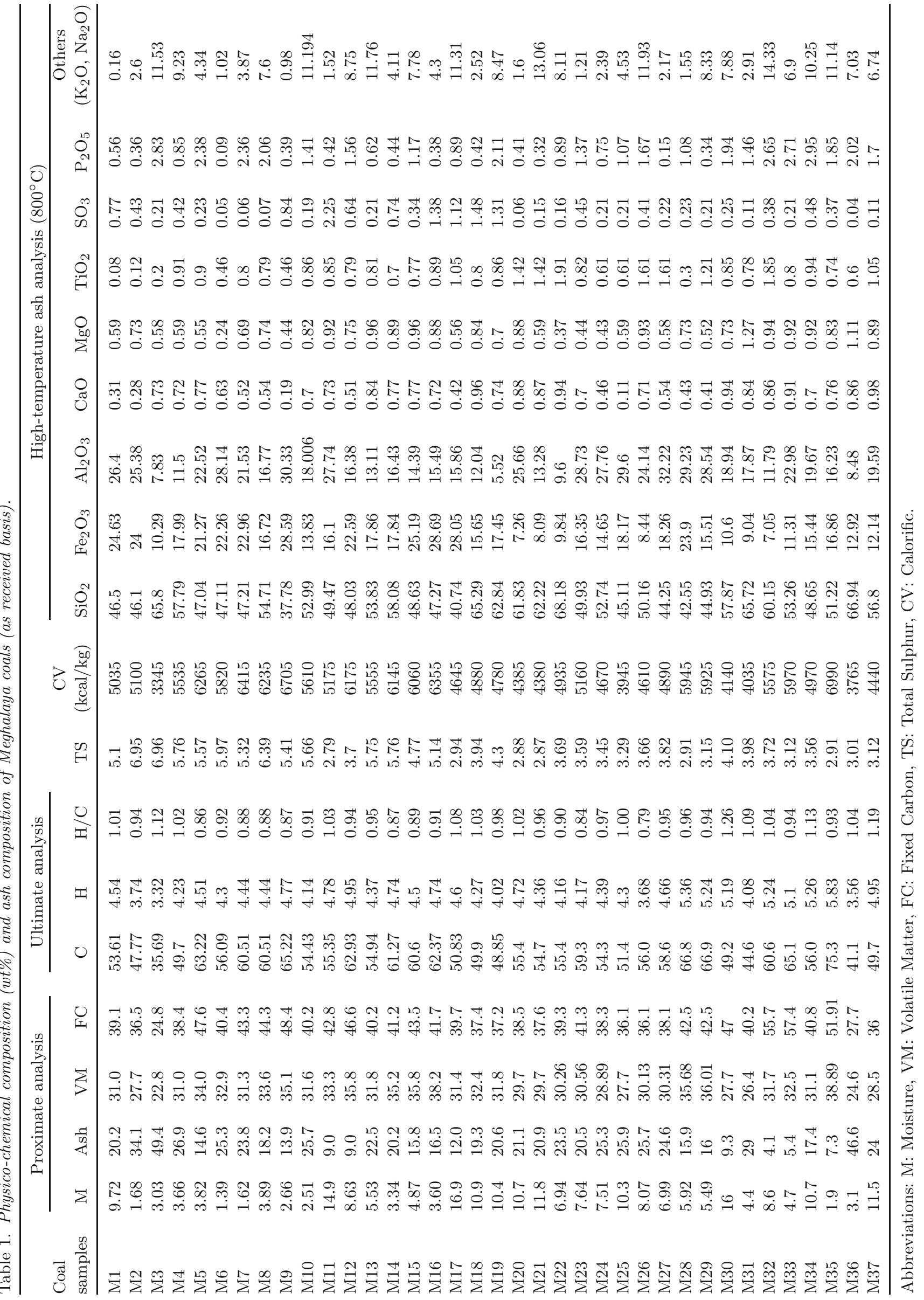




\subsection{Major oxides present in Meghalaya coals}

Meghalaya coals are characterized by relatively low ash contents compared to other Indian coals due to their origin. The study of major oxides and their association with these coals is limited. The composition of major oxides found in these coals (table 1 ) are in the range of $\mathrm{SiO}_{2}(37.78-68.18 \%), \mathrm{Fe}_{2} \mathrm{O}_{3}$ (7.05-28.69\%), $\mathrm{Al}_{2} \mathrm{O}_{3}(5.52-32.22 \%), \mathrm{CaO}(0.11-$ $0.96 \%), \mathrm{MgO}(0.24-1.27 \%), \mathrm{TiO}_{2}(0.08-1.91 \%)$, $\mathrm{SO}_{3}(0.05-2.25 \%), \mathrm{P}_{2} \mathrm{O}_{5}(0.15-2.95 \%)$, and others (0.16-14.33\% of $\mathrm{K}_{2} \mathrm{O}$ and $\left.\mathrm{Na}_{2} \mathrm{O}\right)$.

The ash composition of Meghalaya coals is dominated by $\mathrm{SiO}_{2}$ followed by $\mathrm{Fe}_{2} \mathrm{O}_{3}$ and $\mathrm{Al}_{2} \mathrm{O}_{3}$. Experimental studies carried out by Vassilev et al. (2010a, b) suggest that the high silica contents in the coal are characteristics of high rank coal while their low concentrations are typical of lignites. The majority of the silica contents in the studied coal samples when compared with the datasets given by Vassilev et al. (2010a, b) lead them to the subbituminous category. It has been reported (Baruah 2008) that in northeast Indian coals, the major minerals (wt\% >5) identified in the crystalline matter of coal are quartz, kaolin, illite, feldspar, calcite, pyrite, and gypsum. Vassilev et al. (2010a, b) reported that the rank of the coal increases with the increase of $\mathrm{SiO}_{2}, \mathrm{Al}_{2} \mathrm{O}_{3}$, and $\mathrm{TiO}_{2}$ contents while the rank decreases with the increase of $\mathrm{Fe}_{2} \mathrm{O}_{3}$, $\mathrm{CaO}, \mathrm{SO}_{3}, \mathrm{MgO}, \mathrm{K}_{2} \mathrm{O}$, and $\mathrm{Na}_{2} \mathrm{O}$. The rank of the Meghalaya coals on the basis of the concentrations of the major oxides present in the coal ashes (table 1) can be categorized as ligno-bituminous in comparison to other Indian coal ashes.

The XRD analysis of some of the Meghalaya coal ash samples (M33-M37) has been carried out to assess the mineralogy. The XRD study (figure 2) reveals that the minerals present in these coal ash samples are silicates, carbonates, phosphates, hydroxides, oxides, sulfates, and sulphides which have also been reported earlier (Nayak 2013). The silicate minerals found in these coals are mostly quartz $\left(\mathrm{SiO}_{2}\right)$, feldspar $\left(\mathrm{KAlSi}_{3} \mathrm{O}_{8}\right)$, mica $\left[\mathrm{KAl}_{2} \mathrm{AlSi}_{3} \mathrm{O}_{10}(\mathrm{OH}, \mathrm{F})_{2}\right]$, chlorite $\left[(\mathrm{Mg}, \mathrm{Fe})_{5} \mathrm{Al}_{2} \mathrm{Si}_{3} \mathrm{O}_{10}(\mathrm{OH})_{8}\right]$, and kaolinite $\left[\mathrm{Al}_{2} \mathrm{Si}_{2} \mathrm{O}_{5}(\mathrm{OH})_{4}\right]$. Oxides present in the form of hematite $\left(\mathrm{Fe}_{2} \mathrm{O}_{3}\right)$ and rutile $\left(\mathrm{TiO}_{2}\right)$ and hydroxides as gibbsite $\left[\mathrm{Al}(\mathrm{OH})_{3}\right]$ and goethite $(\mathrm{FeOOH})$. The carbonate group of minerals are present in the form of calcite $\left(\mathrm{CaCO}_{3}\right)$ and siderite $\left(\mathrm{FeCO}_{3}\right)$ whereas phosphate minerals in these coals occur in the form of monazite [(Ce, La, Th, Nd) $\left.\mathrm{PO}_{4}\right]$ and apatite $\left[\mathrm{Ca}_{5} \mathrm{~F}\left(\mathrm{PO}_{4}\right)_{3}\right]$. These mineral phases found from XRD analysis indicate that the studied coal ash samples contain characteristics of both detrital and authigenic nature. The sulphides present in these coals are pyrites $\left(\mathrm{FeS}_{2}\right)$, marcasites $\left(\mathrm{FeS}_{2}\right)$, and sphalerites $(\mathrm{ZnS})$, while the sulphates are present in the form of gypsum $\left(\mathrm{CaSO}_{4} \cdot 2 \mathrm{H}_{2} \mathrm{O}\right)$ and barite $\left(\mathrm{BaSO}_{4}\right)$, both being authigenic minerals. The presence of pyrite in these coals may be due to the transformation of Fe-sulphides to pyrites by the reaction with dissolved sulphides or polysulphides, which may also support the marine influence on Meghalaya coals (Nayak 2013). Ti-bearing phaserutile is recorded to occur in close association with Al-bearing phases-gibbsite and kaolinitic clay, indicating detrital origin (Nayak 2013; Vassilev and Vassileva 1996a).

The origin of the major oxides present in the coal can be either detrital, authigenic, or both depending upon the nature of the source area, depositional conditions, and mode of occurences. The presence of silica concentration in the coal may be attributed to the supply of detrital silica minerals (mostly quartz) and other silicates from source area; weathering of detrital alkaline silicates (feldspars, mica) associated with coal or non-coaly strata; biogenic silica origin (for some coals); or solutions enriched in Si from different sources (Vassilev and Vassileva 1996a).

The $\mathrm{Al}$ present in coal may originate from detrital aluminosilicates and Al-oxyhydroxides from the source area; authigenic clay minerals (especially kaolinite), zeolites, alunite and goyazite, and stable $\mathrm{Al}$ products resulted from weathering of alkaline aluminosilicates; or biogenic $\mathrm{Al}$ origin (Vassilev et al. 2010a, b) The abundance of Fe in coal is related mainly to the occurrence of Febearing minerals like authigenic Fe sulphides and carbonates; Fe sulphates and hydroxides resulted from weathering of $\mathrm{Fe}$ sulphides and carbonates and detrital Fe containing montmorillonite, chlorite, oxyhydroxides, and Fe-spinel. The $\mathrm{Ca}$ and $\mathrm{Mg}$ in coal may be derived from the authigenic Ca- and Mg-bearing carbonates, sulphates, phosphates, and organic minerals; from organically bound biogenic origin such as plant precursors and fossil remains; precipitation of water solutions; or by occurrence of detrital and authigenic bearing minerals. Ti may have originated from organically bound $\mathrm{Ti}$ in coal; detrital supply or authigenic formation of Ti-containing clay and mica minerals; or detrital material enriched in accessory and stable Tibearing minerals such as rutile, anatase, brookite, ilmenite, and titanite (sphene). The sulphur and $\mathrm{SO}_{3}$ presence in coal is related to the authigenic formation of sulphides, sulphates and occasionally elemental S; organically bound S; or mineralized water in coals (particularly in lignites), which is commonly enriched in sulphate ion. High amount of sulphur could also be due to the influence of marine sources during its formation.

$\mathrm{P}_{2} \mathrm{O}_{5}$ might have originated from both the authigenic and detrital minerals in phosphates; originate from the decay of plant debris as phosphorous is 


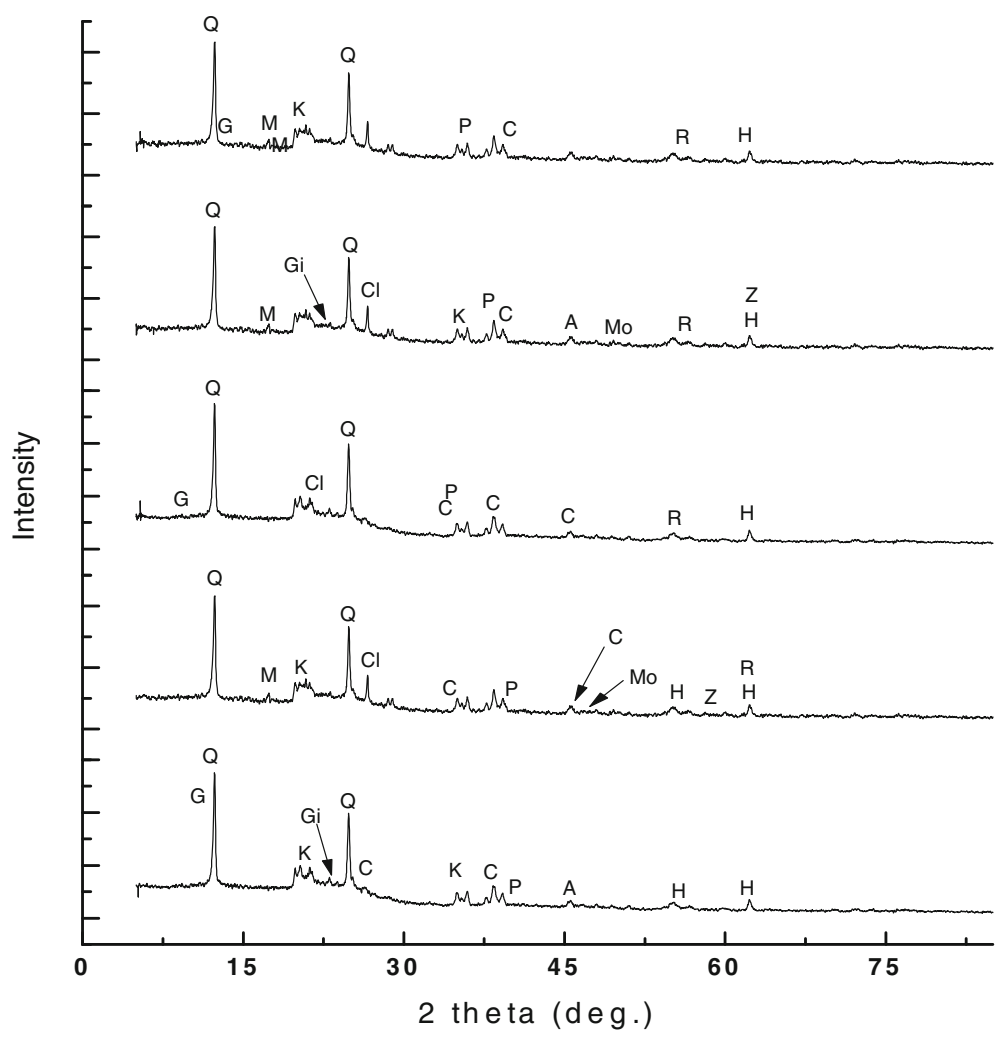

Figure 2. XRD spectras of the Meghalaya coal ash samples [Q: Quartz; G: Gypsum; K: Kaolinite; Cl: Chlorite; C: Calcite; Gi: Gibbsite; H: Hematite; A: Apatite; R: Rutile; M: Marcasite; Z: Sphalerite; P: Pyrite; Mo: Monazite].

a biophilic element and also found in coal seams mainly due to marine invasion; or presence of phosphate bearing rock such as shales, mudstone, basalts, sandstones, and tuffs in source areas.

The availability of $\mathrm{K}$ and $\mathrm{Na}$ in coals may also be due to the supply of detrital K- and Na-bearing silicates from source area; weathering of detrital alkaline silicates associated with coal or noncoaly strata; authigenic formation of $\mathrm{K}$ - and Nacontaining sulphates, chlorides and silicates and organically bound $\mathrm{K}$ and $\mathrm{Na}$ including plant debris as $\mathrm{K}$ and $\mathrm{Na}$ are biophilic elements; or $\mathrm{K}$ - and Na-sulphates resulted from weathering of sulphides and precipitation of water solutions from marine sources (Vassilev et al. 2010a, b). The minerals present in the coal can be classified both as authigenic and detrital in nature based on their origin, mode of occurrences and the prevailing environmental conditions during coal formation.

\subsection{Statistical analyses}

\subsubsection{Relationship between major oxides and ash yield}

The statistically significant correlation coefficient $(r)$ values for the ash and its chemical constituents are listed in table 2. The elements positively correlated with ash are commonly $\mathrm{K}, \mathrm{Al}$, and $\mathrm{Si}$ and $\mathrm{Fe}, \mathrm{Ca}, \mathrm{Na}$, Ti which may be due to their detrital origin and predominant affinity towards inorganic matter in coal (Krejci-Graf 1983; Kler et al. 1987; Martineg-Tarazona et al. 1990; Beaton et al. 1991; Vassilev et al. 1997, 2010a). Trends inverse to the ash yields have been found for elements such as $\mathrm{Si}, \mathrm{Ca}, \mathrm{Mg}$, and $\mathrm{Na}$ indicating their predominant affinity to organic matter in coal and also attribute their authigenic origin (Krejci-Graf 1983; Vassilev et al. 2010a). The authigenic minerals are dominant in most of the low ash coals (8-10 wt\%), while in high ash coals, with the increase of detrital minerals, the concentration of organically bound elements decrease (Nicholls 1969; Vassilev et al. 1997). $\mathrm{Si}$ and $\mathrm{Al}$ are the major components of detrital ash (Vassilev et al. 2010a).

In the present study, it reveals that the studied coal ashes do not show any relation with the major oxides, no such relation as given above is evident from the table 2 . These coals show different behaviour in comparison to similar rank coals due to their different physico-chemical properties, recent origin, and marine influence during coal formation. These coals yield low to medium range ash contents with higher percentage of $\mathrm{Si}$ and $\mathrm{Al}$ 
Table 2. Bivariant analysis of coal ash and its compositions (wt\%).

\begin{tabular}{lccccccrrrr}
\hline Variables & $\mathrm{SiO}_{2}$ & $\mathrm{Fe}_{2} \mathrm{O}_{3}$ & $\mathrm{Al}_{2} \mathrm{O}_{3}$ & $\mathrm{CaO}$ & $\mathrm{MgO}$ & $\mathrm{TiO}_{2}$ & $\mathrm{SO}_{3}$ & $\mathrm{P}_{2} \mathrm{O}_{5}$ & $\mathrm{Others}$ & $\mathrm{Ash}$ \\
\hline $\mathrm{SiO}_{2}$ & $\mathbf{1}$ & $\mathbf{- 0 . 7 3 9}$ & $\mathbf{- 0 . 6 3 6}$ & $\mathbf{0 . 7 6 7}$ & 0.304 & $\mathbf{0 . 4 1 3}$ & -0.091 & 0.125 & 0.242 & 0.164 \\
$\mathrm{Fe}_{2} \mathrm{O}_{3}$ & $-\mathbf{0 . 7 3 9}$ & $\mathbf{1}$ & 0.188 & $-\mathbf{0 . 6 7 1}$ & -0.300 & $-\mathbf{0 . 6 1 6}$ & 0.323 & -0.269 & -0.354 & -0.036 \\
$\mathrm{Al}_{2} \mathrm{O}_{3}$ & $-\mathbf{0 . 6 3 6}$ & 0.188 & $\mathbf{1}$ & $-\mathbf{0 . 5 3 8}$ & -0.303 & -0.283 & -0.129 & -0.278 & $-\mathbf{0 . 6 3 6}$ & 0.087 \\
$\mathrm{CaO}$ & $\mathbf{0 . 7 6 7}$ & $\mathbf{- 0 . 6 7 1}$ & $\mathbf{- 0 . 5 3 8}$ & $\mathbf{1}$ & $\mathbf{0 . 4 3 2}$ & $\mathbf{0 . 4 9 7}$ & -0.070 & 0.283 & 0.339 & -0.124 \\
$\mathrm{MgO}$ & 0.304 & -0.300 & -0.303 & $\mathbf{0 . 4 3 2}$ & $\mathbf{1}$ & 0.059 & 0.122 & 0.327 & 0.243 & -0.129 \\
$\mathrm{TiO}_{2}$ & $\mathbf{0 . 4 1 3}$ & $-\mathbf{0 . 6 1 6}$ & -0.283 & $\mathbf{0 . 4 9 7}$ & 0.059 & $\mathbf{1}$ & -0.156 & 0.132 & $\mathbf{0 . 5 1 1}$ & -0.102 \\
$\mathrm{SO}_{3}$ & -0.091 & 0.323 & -0.129 & -0.070 & 0.122 & -0.156 & $\mathbf{1}$ & -0.232 & -0.173 & -0.295 \\
$\mathrm{P}_{2} \mathrm{O}_{5}$ & 0.125 & -0.269 & -0.278 & 0.283 & 0.327 & 0.132 & -0.232 & $\mathbf{1}$ & 0.421 & -0.373 \\
$\mathrm{Others}$ & 0.242 & -0.354 & $-\mathbf{0 . 6 3 6}$ & 0.339 & 0.243 & $\mathbf{0 . 5 1 1}$ & -0.173 & $\mathbf{0 . 4 2 1}$ & $\mathbf{1}$ & -0.253 \\
Ash & 0.164 & -0.036 & 0.087 & -0.124 & -0.129 & -0.102 & -0.295 & -0.373 & -0.253 & $\mathbf{1}$ \\
\hline
\end{tabular}

$*$ The significant $r$ values at $99 \%$ confidence level are: $\geq 0.40$ and $\leq-0.40$ for 37 variables.

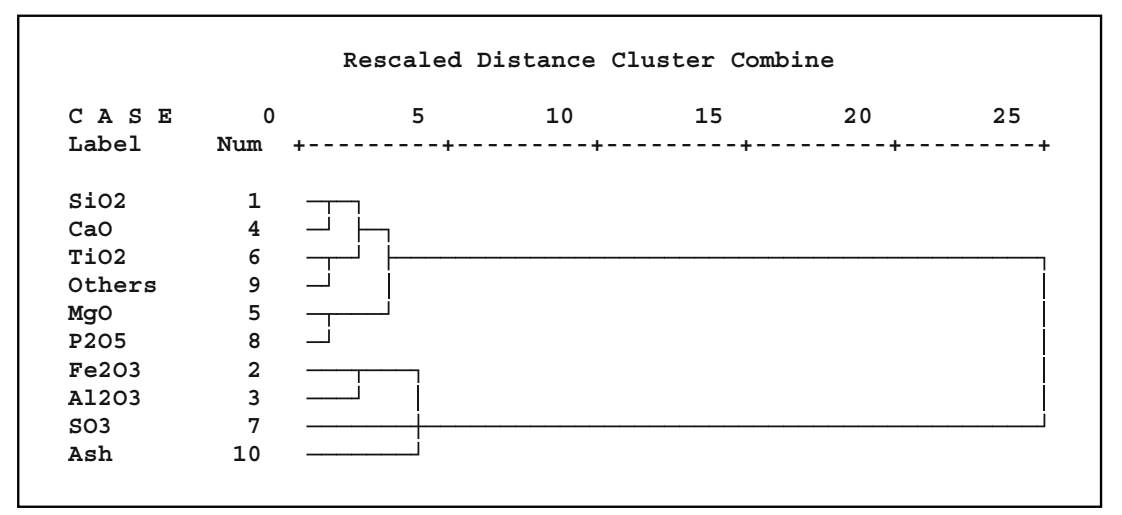

Figure 3. Hierarchical clustering analysis (HCA) of coal ash and its chemical composition.

(in the form of clay minerals) representing the detrital origin of these studied coal samples.

\subsubsection{Relationship between oxides}

Correlation coefficients among the major oxides of Meghalaya coal ashes, as seen from table 2, show that $\mathrm{SiO}_{2}$ has a strong positive correlation with $\mathrm{CaO}$, weak positive correlation with $\mathrm{TiO}_{2}$, and strong negative correlations with $\mathrm{Fe}_{2} \mathrm{O}_{3}$ and $\mathrm{Al}_{2} \mathrm{O}_{3}$. The Ca-bearing minerals found in the studied coal ash samples in the form of authigenic minerals such as calcite, apatite, and gypsum and their strong positive relation with $\mathrm{SiO}_{2}$ indicates their authigenic origin. This strong negative relationship of silica with $\mathrm{Fe}_{2} \mathrm{O}_{3}$ and $\mathrm{Al}_{2} \mathrm{O}_{3}$ was due to their different origins. $\mathrm{Fe}_{2} \mathrm{O}_{3}$ negatively correlates with $\mathrm{CaO}$ and $\mathrm{TiO}_{2}$ whereas $\mathrm{Al}_{2} \mathrm{O}_{3}$ negatively correlates with $\mathrm{CaO}, \mathrm{Na}_{2} \mathrm{O}$, and $\mathrm{K}_{2} \mathrm{O}$. CaO shows weak positive correlation with $\mathrm{MgO}$ and $\mathrm{TiO}_{2}$, while $\mathrm{Na}_{2} \mathrm{O}$ and $\mathrm{K}_{2} \mathrm{O}$ are positively correlated with $\mathrm{TiO}_{2}$. The detrital Ti-bearing minerals are very stable species and concentrated in coal during coal formation, metamorphism, and weathering (Vassilev and Vessileva 2009). This may be one of the reasons for $\mathrm{Ti}$ concentrations in Meghalaya coals.

\subsubsection{Hierarchical Clustering Analysis (HCA)}

Two major clusters are obtained by the cluster analysis (figure 3 ); the first cluster comprising of five subsections including $\mathrm{SiO}_{2}, \mathrm{CaO}, \mathrm{P}_{2} \mathrm{O}_{5}$, others $\left(\mathrm{K}_{2} \mathrm{O}, \mathrm{Na}_{2} \mathrm{O}\right), \mathrm{MgO}$, and $\mathrm{TiO}_{2}$, while the second cluster has three sub-sections including $\mathrm{Fe}_{2} \mathrm{O}_{3}, \mathrm{Al}_{2} \mathrm{O}_{3}, \mathrm{SO}_{3}$ and ash. The first cluster comprises mostly of detrital minerals showing a greater variance within the group, while the second cluster comprises of authigenic minerals. In this analysis, it is found that HCA groups the major oxides along with ash yield based on their pairwise similarity to form common groups until all of them form a single group.

\subsubsection{Principal Component Analysis (PCA)}

The ash contents and their composition were selected for the principal component analysis due to their continuity of measurement in time scale. 
Table 3. Eigen values and \% variability by principal components.

\begin{tabular}{lrrrrrrrrr}
\hline & F1 & \multicolumn{1}{c}{ F2 } & \multicolumn{1}{c}{ F3 } & F4 & F5 & F6 & F7 & F8 & F9 \\
\hline Eigenvalue & 3.882 & 1.636 & 1.292 & 0.987 & 0.888 & 0.570 & 0.327 & 0.259 & 0.159 \\
Variability (\%) & 38.822 & 16.360 & 12.917 & 9.868 & 8.877 & 5.697 & 3.275 & 2.594 & 1.590 \\
Cumulative (\%) & 38.822 & 55.182 & 68.099 & 77.967 & 86.844 & 92.541 & 95.816 & 98.410 & 100.00 \\
\hline
\end{tabular}

Table 4. Results of principal component analysis.

\begin{tabular}{lrrr}
\hline $\begin{array}{l}\text { Ash } \\
\text { compositions }\end{array}$ & \multicolumn{1}{c}{$\mathrm{F} 1$} & \multicolumn{1}{c}{$\mathrm{F} 2$} & \multicolumn{1}{c}{$\mathrm{F} 3$} \\
\hline $\mathrm{SiO}_{2}$ & $\mathbf{0 . 8 0 3}$ & 0.334 & 0.376 \\
$\mathrm{Fe}_{2} \mathrm{O}_{3}$ & $-\mathbf{0 . 7 8 7}$ & -0.387 & 0.105 \\
$\mathrm{Al}_{2} \mathrm{O}_{3}$ & $\mathbf{- 0 . 6 9 4}$ & 0.258 & -0.302 \\
$\mathrm{CaO}$ & $\mathbf{0 . 8 5 1}$ & 0.078 & 0.227 \\
$\mathrm{MgO}$ & 0.490 & -0.309 & 0.264 \\
$\mathrm{TiO}_{2}$ & $\mathbf{0 . 6 6 4}$ & 0.182 & -0.203 \\
$\mathrm{SO}_{3}$ & -0.181 & $-\mathbf{0 . 5 3 2}$ & $\mathbf{0 . 6 9 9}$ \\
$\mathrm{P}_{2} \mathrm{O}_{5}$ & 0.477 & -0.434 & $-\mathbf{0 . 5 0 1}$ \\
$\mathrm{Others}_{2}\left(\mathrm{~K}_{2} \mathrm{O}, \mathrm{Na}_{2} \mathrm{O}\right)$ & $\mathbf{0 . 6 7 0}$ & -0.301 & -0.332 \\
Ash & -0.150 & $\mathbf{0 . 7 8 2}$ & 0.189 \\
\hline
\end{tabular}

During principal component analysis of these data, a correlation matrix was followed. For better representation, the components with an eigen value of $<1$ should be eliminated so that fewer components are dealt with (Chatfield and Collin 1980). During analysis, the first three components are extracted and the other components are eliminated. When the percentages of the total variances of the three extracted components are accumulated, it can be seen that these three principal components account for $68.099 \%$ of the total variance of the original data (table 3). Variables having a loading more than 0.5 are only considered to explain each factor (Khare et al. 2011) (table 4).

From tables 3 and 4, the factor 1 accounts for $38.82 \%$ of total variance in the observed variables and is associated positively with $\mathrm{SiO}_{2}, \mathrm{CaO}, \mathrm{TiO}_{2}$, $\mathrm{K}_{2} \mathrm{O}$, and $\mathrm{Na}_{2} \mathrm{O}$, while negatively with $\mathrm{Fe}_{2} \mathrm{O}_{3}$ and $\mathrm{Al}_{2} \mathrm{O}_{3}$. The high loadings of both $\mathrm{CaO}$ and $\mathrm{SiO}_{2}$ reflect that both of them are related and their close linkage can be seen in cluster analysis (figure 3 ). $\mathrm{SiO}_{2}, \mathrm{Fe}_{2} \mathrm{O}_{3}, \mathrm{Al}_{2} \mathrm{O}_{3}, \mathrm{TiO}_{2}, \mathrm{~K}_{2} \mathrm{O}$, and $\mathrm{Na}_{2} \mathrm{O}$ are related to the calcium oxide content of the coal ash. The negative score of $\mathrm{Fe}_{2} \mathrm{O}_{3}$ and $\mathrm{Al}_{2} \mathrm{O}_{3}$ in this factor indicates that these coals have more of the detrital minerals than authigenic ones. The factor 2 accounts for $16.36 \%$ of the total variance, whereas it is associated negatively with the $\mathrm{SO}_{3}$ and positively with ash, indicating that the sulphur is mostly present in coals as organic sulphur, thus signifying decrease of $\mathrm{SO}_{3}$ content. The factor 3 accounts for $12.917 \%$ of the total variance showing negative association with $\mathrm{P}_{2} \mathrm{O}_{5}$ and positive association with $\mathrm{SO}_{3}$, indicating that with the decrease of $\mathrm{P}_{2} \mathrm{O}_{5}$ content in the coal, $\mathrm{SO}_{3}$ content increases.

The score plot (figure 4a) and the loading plot (figure 4b) identify the relationship among the similar coal samples (M1-M37) and variables $\left(\mathrm{SiO}_{2}\right.$, $\mathrm{Fe}_{2} \mathrm{O}_{3}, \mathrm{Al}_{2} \mathrm{O}_{3}$, etc.) respectively. The variables and the samples that are closely spaced have high correlation and similar behaviour (figure $4 \mathrm{a}, \mathrm{b}$ and $\mathrm{c}$ ). The relationship between the score plot and loading plot is illustrated in the bi-plot diagram (figure 4c).

\subsection{Coal ash/ash composition as geochemical indicators}

The ash forming elements in coal have affinities towards ash yield, expressed as DAI, mostly indicating the origin of the coal formation. DAI $>8$ indicates highest detrital affinity of ash, while DAI $<3$ indicates highest authigenic affinity of ash (Baruah 2008). The high DAI (table 5) of Meghalaya coals (avg. 4.88) reveal that the coal seams contain high amount of detrital mineral matter and thus may be of allochthonous origin (Korobetskii and Shprit 1988; Vassilev et al. 2010a). The high $\mathrm{SiO}_{2} / \mathrm{Al}_{2} \mathrm{O}_{3}$ ratios (1.25-11.38) (table 5) and increased ash yields (4.1-26.9\%) (table 1) of Meghalaya coal samples indicate that these coals are formed under unstable conditions of deposition, when subsidence in the basin was relatively rapid and irregular, with high degree of tectonic movement (Shibaoka 1972). The $\mathrm{SiO}_{2} / \mathrm{Al}_{2} \mathrm{O}_{3}$ ratios also depend upon the chemical decomposition (leaching) or mechanical erosion of the rocks (Shibaoka 1972; Vassilev et al. 2010a). The high $\mathrm{SiO}_{2} / \mathrm{Al}_{2} \mathrm{O}_{3}$ ratios and higher ash yield $(>12 \%)$ of the coal samples under study indicate the dominance of mechanical erosion over the chemical leaching and also indicate that they are formed under mountain peat-forming environment (Yudovich 1978; Vassilev et al. $2010 \mathrm{~b})$. The low values of $\mathrm{CaO}+\mathrm{MgO} / \mathrm{K}_{2} \mathrm{O}+\mathrm{Na}_{2} \mathrm{O}$ ratios (0.11-5.62) and $\mathrm{CaO} / \mathrm{MgO} \quad(0.19-2.63)$ (table 5) are attributed to marine influence on the coal formation. The high sulphur content in the northeast Indian coals resulted from the increased availability of sulphate ions in sea water coupled with the activity of anaerobic 
Observations (axes F1 and F2: $\mathbf{5 5 . 1 8} \%$ )

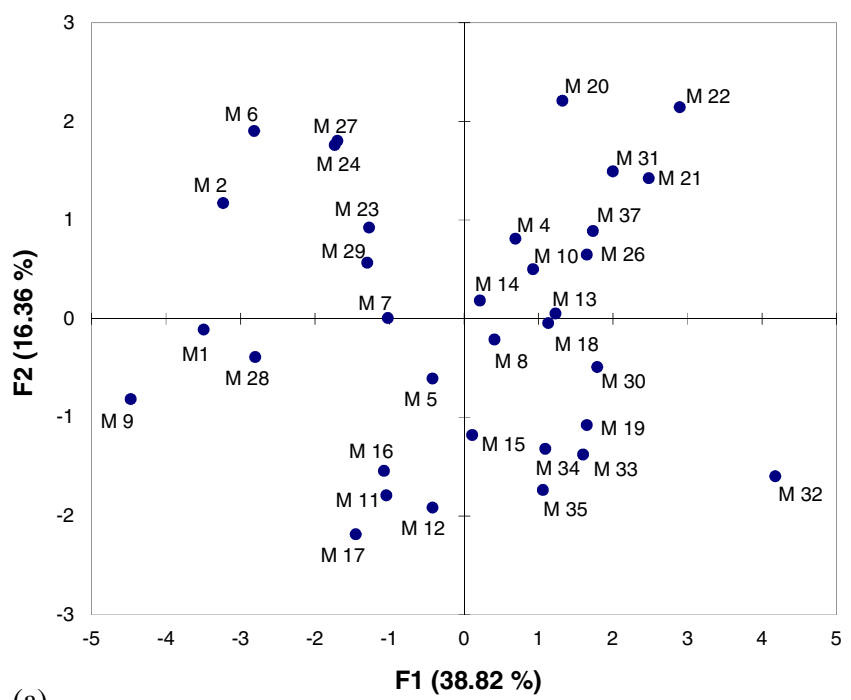

(a)

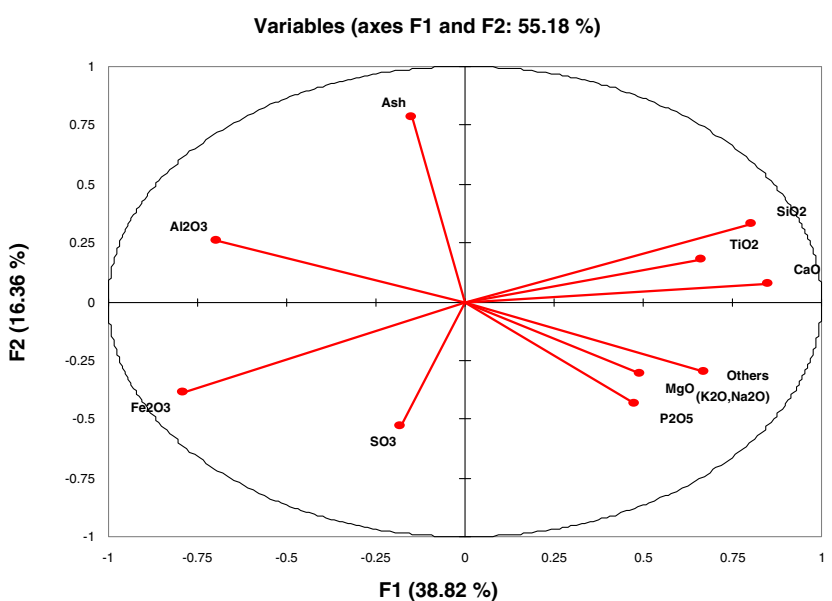

(b)

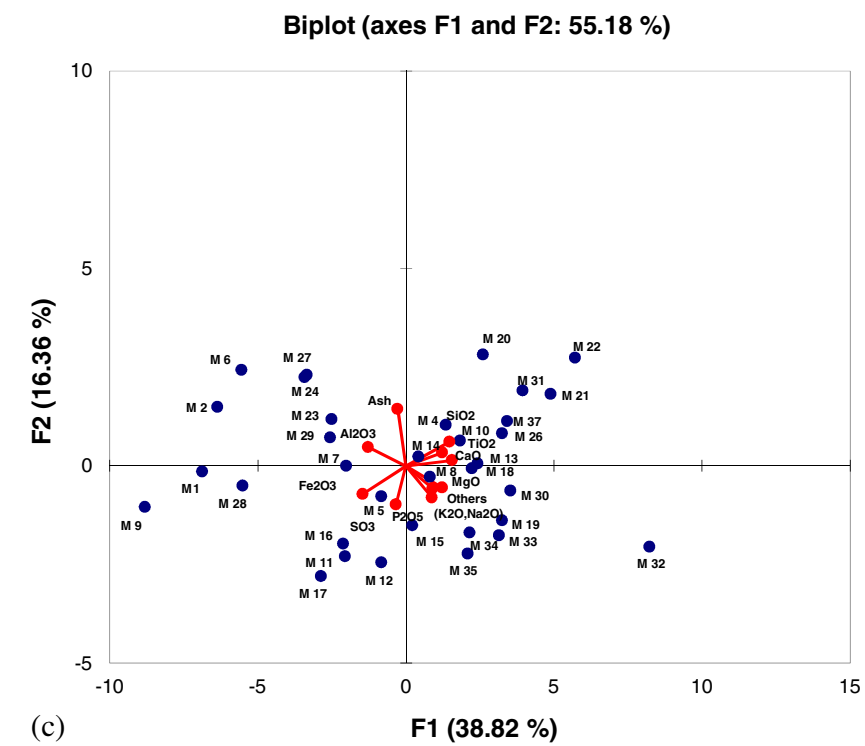

Figure 4. (a) Score plot, (b) loading plot and (c) bi-plot of Principal Component Analysis (PCA).
Table 5. Oxide ratios of the coal samples.

\begin{tabular}{|c|c|c|c|c|c|}
\hline & DAI & $\begin{array}{l}\mathrm{SiO}_{2} / \\
\mathrm{Al}_{2} \mathrm{O}_{3}\end{array}$ & $\begin{array}{l}\mathrm{CaO} / \\
\mathrm{MgO}\end{array}$ & $\begin{array}{c}\mathrm{CaO}+ \\
\mathrm{MgO}\end{array}$ & $\begin{array}{r}(\mathrm{CaO}+\mathrm{MgO}) / \\
\left(\mathrm{K}_{2} \mathrm{O}+\mathrm{Na}_{2} \mathrm{O}\right)\end{array}$ \\
\hline M1 & 2.78 & 1.76 & 0.53 & 0.90 & 5.62 \\
\hline M2 & 2.92 & 1.82 & 0.38 & 1.01 & 0.39 \\
\hline M3 & 7.22 & 8.40 & 1.26 & 1.31 & 0.11 \\
\hline M4 & 4.03 & 5.03 & 1.22 & 1.31 & 0.14 \\
\hline M5 & 3.28 & 2.09 & 1.40 & 1.32 & 0.30 \\
\hline M6 & 3.31 & 1.67 & 2.63 & 0.87 & 0.85 \\
\hline M7 & 3.03 & 2.19 & 0.75 & 1.21 & 0.31 \\
\hline M8 & 4.42 & 3.26 & 0.73 & 1.28 & 0.17 \\
\hline M9 & 2.31 & 1.25 & 0.43 & 0.63 & 0.64 \\
\hline M10 & 5.34 & 2.94 & 0.85 & 1.52 & 0.13 \\
\hline M11 & 3.98 & 1.78 & 0.79 & 1.65 & 1.08 \\
\hline M12 & 3.02 & 2.93 & 0.68 & 1.26 & 0.14 \\
\hline M13 & 4.00 & 4.11 & 0.88 & 1.80 & 0.15 \\
\hline M14 & 3.92 & 3.53 & 0.86 & 1.66 & 0.40 \\
\hline M15 & 2.63 & 3.38 & 0.80 & 1.73 & 0.22 \\
\hline M16 & 2.15 & 3.05 & 0.82 & 1.60 & 0.37 \\
\hline M17 & 2.29 & 2.57 & 0.75 & 0.98 & 0.08 \\
\hline M18 & 4.26 & 5.42 & 1.14 & 1.80 & 0.71 \\
\hline M19 & 3.85 & 11.38 & 1.06 & 1.44 & 0.17 \\
\hline M20 & 9.97 & 2.41 & 1.00 & 1.76 & 1.10 \\
\hline M21 & 9.28 & 4.69 & 1.47 & 1.46 & 0.11 \\
\hline M22 & 7.76 & 7.10 & 2.54 & 1.31 & 0.16 \\
\hline M23 & 4.49 & 1.74 & 1.59 & 1.14 & 0.94 \\
\hline M24 & 5.30 & 1.89 & 1.07 & 0.89 & 0.37 \\
\hline M25 & 4.18 & 1.52 & 0.19 & 0.70 & 0.15 \\
\hline M26 & 8.37 & 2.08 & 0.76 & 1.64 & 0.14 \\
\hline M27 & 4.09 & 1.37 & 0.93 & 1.12 & 0.52 \\
\hline M28 & 2.91 & 1.46 & 0.59 & 1.16 & 0.75 \\
\hline M29 & 4.98 & 1.57 & 0.79 & 0.93 & 0.11 \\
\hline M30 & 6.83 & 3.05 & 1.29 & 1.67 & 0.21 \\
\hline M31 & 7.75 & 3.68 & 0.66 & 2.11 & 0.73 \\
\hline M32 & 9.55 & 5.10 & 0.91 & 1.80 & 0.13 \\
\hline M33 & 6.29 & 2.32 & 0.99 & 1.83 & 0.26 \\
\hline M34 & 4.53 & 2.47 & 0.76 & 1.62 & 0.16 \\
\hline M35 & 4.22 & 3.16 & 0.92 & 1.59 & 0.14 \\
\hline M36 & 5.56 & 7.89 & 0.77 & 1.97 & 0.28 \\
\hline M37 & 5.96 & 2.89 & 1.10 & 1.87 & 0.28 \\
\hline Avg & 4.88 & 3.38 & 0.98 & 1.40 & 0.50 \\
\hline
\end{tabular}

*DAI: $\left(\mathrm{SiO}_{2}+\mathrm{Al}_{2} \mathrm{O}_{3}+\mathrm{K}_{2} \mathrm{O}+\mathrm{TiO}_{2}+\mathrm{Na}_{2} \mathrm{O}\right) /\left(\mathrm{Fe}_{2} \mathrm{O}_{3}+\mathrm{CaO}+\right.$ $\left.\mathrm{SO}_{3}+\mathrm{MgO}\right)$.

bacteria (Baruah 2008; Baruah and Khare 2010). The presence of high sulphur in Meghalaya coal seams (table 1) suggest marine influence as sulphur compounds are quickly formed by oxidation in marine environment, where oceanic sulphate sources have high sulphate reduction rates. During the coal formation, these sulphates are incorporated to the matrix of the coal molecule giving high organic sulphur groups. The presence of foraminiferal limestone with subordinate calcareous bands within sandstone in the coal bearing areas of Meghalaya also asserts marine influence on the area (CMPDI 1991). 


\section{Conclusions}

The Meghalaya coals, belonging to tertiary age, characterized by medium to high ash, high volatile matter, and high sulphur content are classified as ligno-bituminous in rank. The coal ash composition indicates the presence of different elements in these coals representing both detrital and authigenic origin. However, the statistical tools such as correlation, HCA, and PCA analyses have revealed the detrital nature of the ash forming elements in these coals. This study also revealed that the ash yields do not show significant relationship with the oxides present in the coal ash, and hence are not conclusive about the origin of these coals, which may be due to the fact that they have been formed under marine influence. The ratios of different major oxides and DAI used in this investigation as geochemical indicators have confirmed the presence of detrital minerals indicating the detrital origin of these coals that were formed during high degrees of tectonic movement.

\section{Acknowledgement}

The authors are thankful to the Ministry of Steel, Govt. of India, New Delhi and CSIR, New Delhi for financial assistance.

\section{References}

Adolphi P and Storr M 1985 Glow discharge excited low temperature ashing; Fuel 64 151-155.

Beaton A P, Goodarzi F and Potter J 1991 The petrography, mineralogy and geochemistry of a paleocene lignite from southern Saskatchewan, Canada; Int. J. Coal Geol. 17 $117-148$.

Berkowitz N 1979 An Introduction to Coal Technology (London: Academic Press), 345p.

Baruah B P 2008 Environmental studies around Makum coalfield, Margherita (Thesis); 118p.

Baruah B P and Khare P 2010 Sulphur in Tertiary Indian coals; LAP Lambert Academic Publishing GmbH \& Co. KG; ISBN: 978-3-8433-6441-6.

Compendium on the coal occurrences of North Eastern Region, Vol. III, D-Coalfields of Jaintia Hills, Meghalaya; Central Mine Planning and Design Institute Ltd. (A subsidiary of coal India Ltd.), Ranchi, March (1991).

Chatfield C and Collin A J 1980 Introducton to multivariate analysis; Chapman and Hall, London \& New York; ISBN: 0-412-16030-7.

Clark I and Harper W 2000 Practical Geostatistics; 1st edn, Ecosse North America LLC, Columbus, Ohio, USA; $147 \mathrm{p}$.

Dixon K, Skipsey E and Watt J T 1964 The distribution and composition of inorganic matter in British coals. Part 1: Initial study of seams from the east midlands division of the national coal board; J. Inst. Fuel 37 485-493.

Finkelman R B 1988 The inorganic geochemistry of coal: A scanning electron microscopy view; Scanning Microscopy 2(1) 97.
Francis W 1961 Coal: Its formation and composition; 2nd edn (London: Edward Arnold), 806p.

Himus G W 1954 Fuel testing: Laboratory methods in fuel technology (London: Leonard Hill), pp. 67-78.

Jenkins R G and Walker P L 1978 In analytical methods for coal and coal products; vol-II (ed.) Karr CJ Jr, Academic Press, New York, 265p.

Khare P, Baruah B P and Rao P G 2011 Application of chemometrics to study the kinetics of coal pyrolysis: A novel approach; Fuel 90 3299-3305.

Khare P and Baruah B P 2010 Structural parameters of Perhydrous Indian coals; Int. J. Coal Preparation and Utilization 30 44-67.

Kler V R, Volkova G A, Gurvich E M, Dvornokov A G, Jarov Y N and Kler D V et al. 1987 Metallogeny and geochemistry of coal and shale bearing strata in the USSR: Geochemistry of elements, Nauka: Moscow, 240p.

Korobetskii I and Shpirt M 1988 Genesis and properties of the coal mineral components; Nauka, Novosibirsk, $227 \mathrm{p}$.

Krejci-Graf K 1983 Minor elements in coals; In: The Significance of Trace Elements in Solving Petrogenetic Problems and Controversies (ed.) Augustithis S, Theophrastus Publications, Athens, pp. 533-597.

Machowsky M Th 1968 European carboniferous coal fields and Permian Gondwana coal fields; In: Coal and coalbearing strata (eds) Murchison D G and T S Westoll, Oliver Boyd, Edinburg, pp. 325-345.

Martineg-Tarazona M R, Martinez-Alonz A and Tascon J M D 1990 Interactions between carboxyl groups and inorganic elements in Spanish brown coals; Fuel 69 362-367.

Misra B K 1992 Optical properties of some tertiary coal from northeastern India: Their depositional environment and hydrocarbon potential; Int. J. Coal Geol. 20 115-144.

Nascu H I, Comsulea D I and Niac G 1995 The distribution of inorganic elements between coal and mineral matter in Rumanian lignite; Fuel 74 119-123.

Nayak B 2013 Mineral matter and the nature of pyrite in some high sulphur tertiary coals of Meghalaya, northeast India; J. Geol. Soc. India 81 203-214.

Nicholls G D 1969 The geochemistry of coal-bearing strata, In: Coal and Coal bearing Strata (eds) Murchison and Westoll (Edinburgh: Oliver \& Boyd), pp. 269-307.

Shibaoka M 1972 Silica/alumina ratios of the ashes from some Australian coals; Fuel 51 278-283.

Singh M P and Singh A K 2000 Petrographic characteristics and depositional conditions of Eocene coals of platform basins, Meghalaya, India; Int. J. Coal Geol. 42(4) $315-356$.

Stach E, Mackowsky M-Th, Teichmiller M, Taylor G H, Chandra G and Teichmiiller R 1975 Stach's Textbook of Coal Petrology; 2nd edn, Berlin: Gebriiden Borntraeger, $428 \mathrm{p}$.

Thiessen G 1945 Composition and origin of mineral matter in coal; In: Chemistry of Coal Utilization (ed.) Lowry H H (New York: John Willey \& Sons, Inc.) 1 485495.

Van der Flier-Keller E and Fyfe W S 1988 Mineralogy of Lower Cretaceous coals from the Moose River Basin, Ontario, and Monkman, British Columbia; Can. Mineral 26 343-353.

Vassilev S and Vassileva C 1996 Occurrence, abundance and origin of minerals in coals and coal ashes; Fuel Processing Technology 48 85-106.

Vassilev S and Vessileva C 2009 A new approach for the combined chemical and mineral classification of the inorganic in the coal. 1. Chemical and mineral classification system; Fuel 88 235-245. 
Vassilev S V, Kitano K and Vassileva C G 1997 Relationship between ash yield and chemical and mineral composition of coals; Fuel 76(1) 3-5.

Vassilev S V, Vassileva C G, Baxter D and Andersen L K 2010a Relationship between chemical and mineral composition of coal and their potential application as genetic indicators. Part 1. Chemical characteristics; Geologica Balcanica 39.3 Sofia 21-41.
Vassilev S V, Vassileva C G, Baxter D and Andersen L K 2010b Relationship between chemical and mineral composition of coal and their potential application as genetic indicators. Part 2. Mineral classes, groups and species; Geologica Balcanica $\mathbf{3 9 . 3}$ Sofia 43-67.

Yudovich Ya E 1978 Geochemistry of Fossil Coals; Science Publ. House, Moscow: Nauka, Leningrad; 262p.

MS received 27 December 2013; revised 7 May 2014; accepted 17 May 2014 